\title{
Flower Thrips, Frankliniella tritici (Fitch) (Insecta: Thysanoptera: Thripidae) ${ }^{1}$
}

\author{
Danielle Sprague, Joe Funderburk and Andrea Lucky²
}

\section{Introduction}

The flower thrips, Frankliniella tritici (Fitch) (Figure 1 ), is one of the most abundant species of flower thrips (Thysanoptera: Thripidae) in the eastern United States (Reitz 2008). The official common name established by the Entomological Society of America for this species is flower thrips, although the name flower thrips is often applied generically to the numerous species in the genus Frankliniella that inhabit flowers. For this reason, it is frequently referred to as the eastern flower thrips, presumably for its distribution in the eastern United States.

Several species in the genus Frankliniella are considered economic pests and cause damage to a wide variety of crops through feeding and oviposition (Childers 1997). Several species are able to vector orthotospoviruses (or tospoviruses), including Tomato spotted wilt virus. However, Frankliniella tritici is not a vector of Tomato spotted wilt virus and is considered a pest of secondary importance (de Assis Filho 2005).

Frankliniella tritici may, however, be confused with other similar Frankliniella species in Florida such as Frankliniella bispinosa and Frankliniella occidentalis which are capable vectors of Tomato spotted wilt virus (Riley et al. 2011).

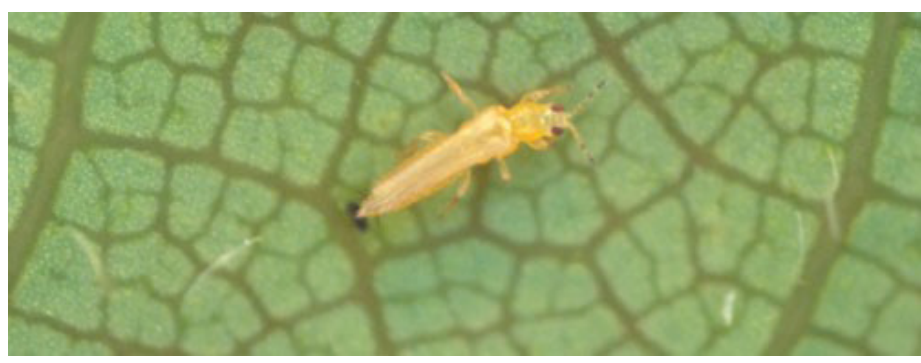

Figure 1. Frankliniella tritici (Fitch) adult. Credits: James Castner, UF/IFAS

\section{Synonymy}

According to Hoddle et al. (2012):

- Thrips tritici Fitch, 1855

- Frankliniella varicorne Bagnall, 1919

- Frankliniella fulvus Moulton, 1936

- Frankliniella tritici f. clara Moulton, 1948

- Frankliniella salicis Moulton, 1948

\section{Distribution}

Frankliniella tritici is native to eastern North America and it is found primarily east of the Rocky Mountains (Cluever and Smith 2016). Frankliniella tritici has also been reported in Asia, the Caribbean and Europe (Cluever and Smith 2016).

1. This document is EENY-720, one of a series of the Entomology and Nematology Department, UF/IFAS Extension. Original publication date December 2018. Visit the EDIS website at https://edis.ifas.ufl.edu for the currently supported version of this publication. This document is also available on the Featured Creatures website at http://entnemdept.ifas.ufl.edu/creatures/.

2. Danielle Sprague; Joe Funderburk, professor; and Andrea Lucky, associate professor; Entomology and Nematology Department, UF/IFAS Extension, Gainesville, FL 32611

The Institute of Food and Agricultural Sciences (IFAS) is an Equal Opportunity Institution authorized to provide research, educational information and other services

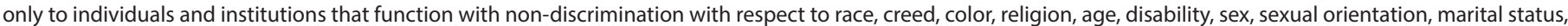

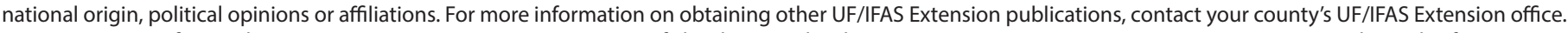
U.S. Department of Agriculture, UF/IFAS Extension Service, University of Florida, IFAS, Florida A \& M University Cooperative Extension Program, and Boards of County Commissioners Cooperating. Nick T. Place, dean for UF/IFAS Extension. 


\section{Description}

Eggs: The eggs of Frankliniella tritici are kidney shaped and approximately $0.4 \mathrm{~mm}$ in length (Arthurs et al. 2015). Adult females deposit eggs in plant tissue and may lay up to 17 eggs per day (Reitz 2008).

Larva: Larvae are wingless, yellow and resemble adults. They are elongate and oval and approximately $0.5 \mathrm{~mm}$ in length (Cluever and Smith 2016).

Pupa: Propupa have wing buds and the antennae are straight, whereas the pupa has the antennae pulled back over the head (Cluever and Smith 2016). Pupa range in size from $0.5 \mathrm{~mm}$ to $1 \mathrm{~mm}$ in length.

Frankliniella tritici larvae and pupae closely resemble other Frankliniella species and are not typically identified to species in this stage (Cluever and Smith 2016).

Adults: Adults possess fringed wings and are yellow in color (Figure 2). Adults are elongate, and approximately 1 $\mathrm{mm}$ in length (Arthurs et al. 2015).

Adults examined at high magnification may be distinguished from other pale Frankliniella species found in Florida by a combination of diagnostic features provided below.

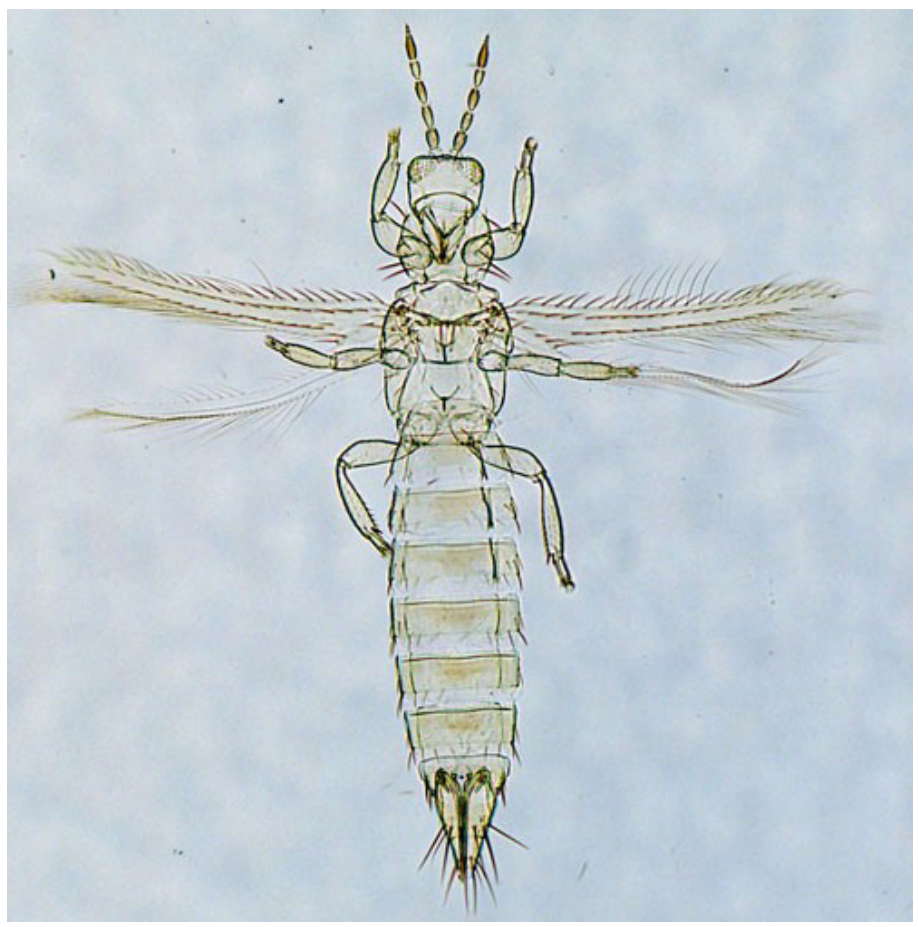

Figure 2. Slide mounted Frankliniella tritici (Fitch) adult female.

Credits: Thomas Skarlinsky, United States Department of Agriculture, Animal and Plant Health Inspection Service.

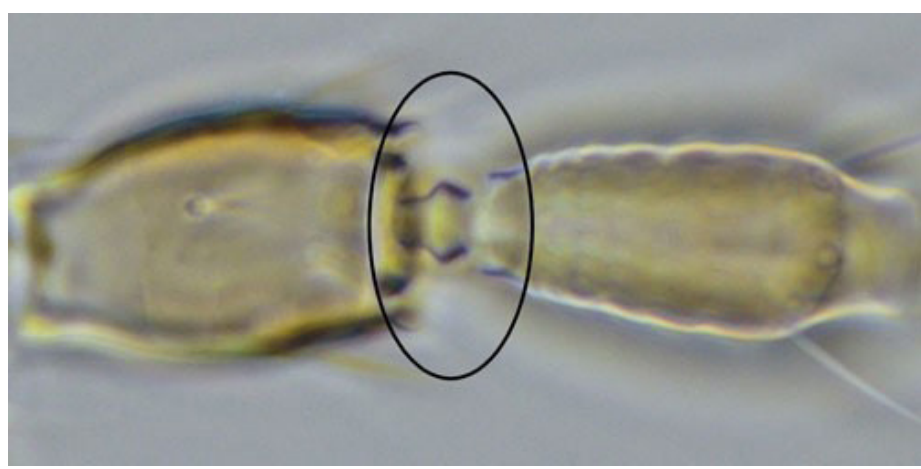

Figure 3. Setae arising from antennal segment II of Frankliniella tritici (Fitch) are simple. The antennal segment three pedicel is swollen and mushroom-like (circled).

Credits: Thomas Skarlinsky, United States Department of Agriculture, Animal and Plant Health Inspection Service.

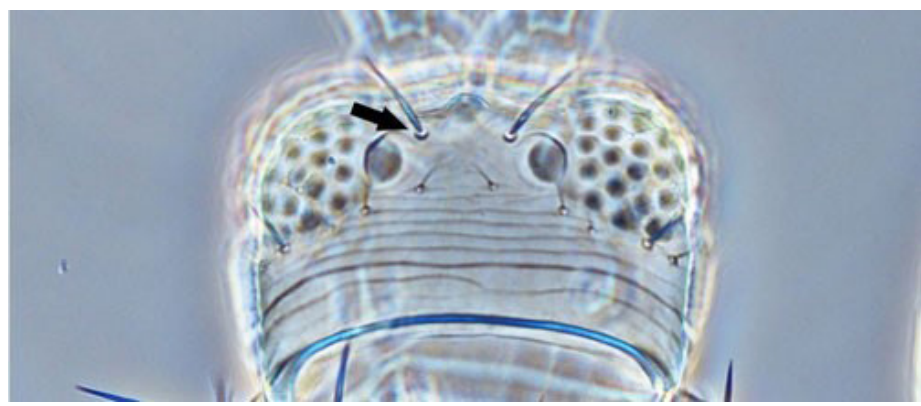

Figure 4. Three pairs of ocelli setae arise on anterior margins of the ocellar triangle of Frankliniella tritici (Fitch).

Credits: Thomas Skarlinsky, United States Department of Agriculture, Animal and Plant Health Inspection Service.

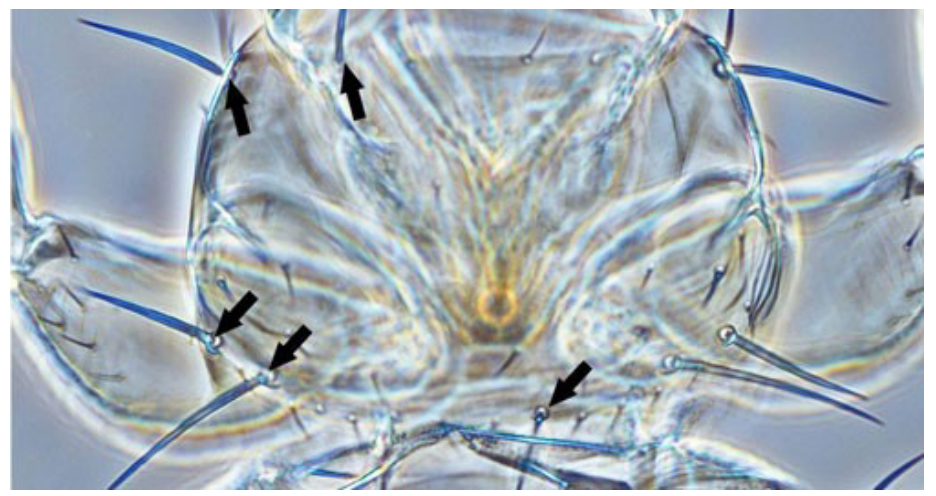

Figure 5. Pronotum of Frankliniella tritici (Fitch) with five pairs of major setae (arrowed).

Credits: Thomas Skarlinsky, United States Department of Agriculture, Animal and Plant Health Inspection Service. 


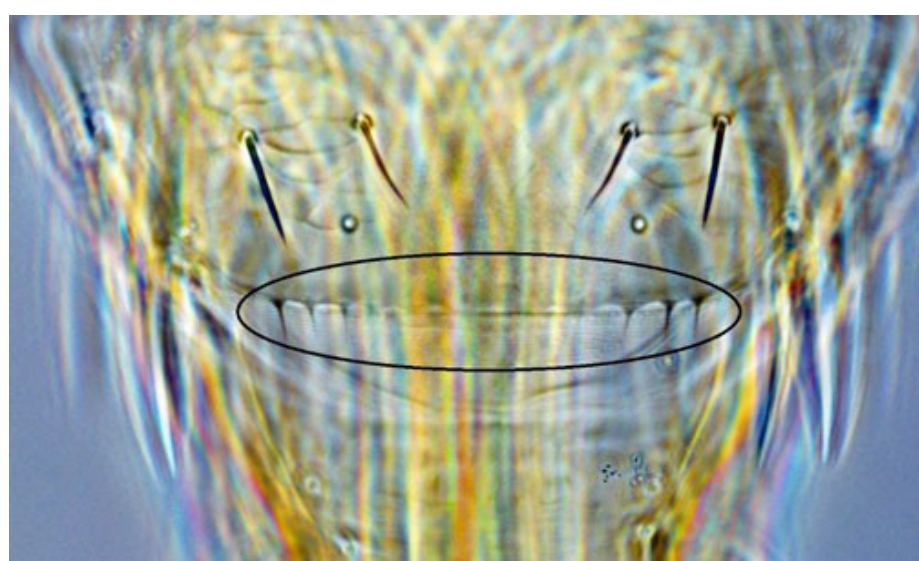

Figure 6. Posterior margin of abdominal segment eight of Frankliniella tritici (Fitch) with incomplete microtrichial comb.

Credits: Thomas Skarlinsky, United States Department of Agriculture, Animal and Plant Health Inspection Service.

\section{Life Cycle}

Frankliniella tritici are haplodiploid; males are produced from unfertilized eggs and diploid females are produced from fertilized eggs (Reitz 2009).

The life cycle of Frankliniella tritici consists of an egg, two larval stages, prepupa, pupa and adult (Childers 1997).

Frankliniella tritici feed on plant tissue during the larval and adult stages, but the pupal stages are found in the soil and do not feed (Arthurs et al. 2015). The developmental time from egg to adult is approximately two to three weeks (Reitz 2008) with a minimum development temperature of $10^{\circ} \mathrm{C}$ (Toapanta 2001). Adults lay eggs in plant tissue and can lay up to 17 eggs per day (Reitz 2008). Larvae and adults are highly mobile and found in the flower or on the fruit of host plants (Funderburk et al. 2015b). Adults live for approximately 38 days (Reitz 2008). Frankliniella tritici have multiple generations per year and populations develop more rapidly as temperature increase (Funderburk et al. 2015a, 2015b).

\section{Hosts}

Frankliniella tritici infests the flowers of a wide variety of agricultural crops including asparagus, blackberry, cotton, eggplant, peach, pepper, rye, soybean, strawberry, and tomato (Funderburk et al. 2015a, 2015b, Cluever and Smith 2016). Frankliniella tritici is found in ornamentals such as chrysanthemum and rose (Cluever and Smith 2016). In addition to agricultural crops and ornamentals, Frankliniella tritici has been recorded from several species of flowering weeds including morning glory, dandelion, wood sorrel, and clover (Chellemi et al. 1994). In a study in northern Florida, Frankliniella tritici were collected from 48 plant species over the course of one year with 18 plants identified as reproductive hosts (Paini et al. 2007).

\section{Economic Importance}

In the southeastern United States, Frankliniella tritici, along with other Frankliniella species, is recognized as an early-season pest of seedling cotton (Reed et al. 2006). Adults feed on the new terminal growth and underside of the leaves (Cotton Insect Management Guide 2017) causing silvering of the plant tissue and a reduction in photosynthesis (Kirk 2002). Plants damaged by thrips may be stunted and leaves may be distorted.

In northern Florida, Frankliniella tritici is the most common species of thrips found in the flowers of eggplant, pepper and tomato; however, they are not damaging, even at densities of 20 to 25 adults per flower (Demirozer et al. 2012, Funderburk et al. 2015a, 2015b). Frankliniella tritici has been shown to outcompete the highly damaging western flower thrips, Frankliniella occidentalis (Paini et al. 2008).

\section{Management}

Scouting: Scouting for thrips in fruiting vegetables is done by selecting blooms and counting the number of thrips after tapping the bloom against a whiteboard (Schuster and Smith 2015). All fruit sizes are examined directly for thrips (Funderburk et al. 2015a, 2015b).

Scouting in cotton is done by beating the plants over a whiteboard and counting the number of thrips (Layton and Reed 2014). The Texas A\&M University Cotton Insect Management Program (2017) recommends scouting for thrips weekly until cotton has five to seven leaves.

Thrips are preserved for identification by placing flowers, leaves or buds in a small container with $70 \%$ ethyl alcohol. Thrips in the alcohol are extracted and identifications are made using a 40X magnification stereoscope (Funderburk et al. 2015a, 2015b).

Economic Thresholds: Proper identification of thrips in cropping systems is a critical component to a successful integrated pest management program. Different species of Frankliniella occur in eggplant, pepper, and tomato in Florida and vary greatly in their pest status (Demirozer et al. 2012). Densities of 10 or more Frankliniella tritici adults per flower are tolerated before action is recommended; however, a threshold of one Frankliniella occidentalis adult per flower in tomato and six adults per flower in eggplant and pepper are the recommended economic threshold 
(Demirozer et al. 2012). This emphasizes the proper identification of thrips species in fruiting vegetables.

In cotton production, established economic thresholds for thrips do not identify a certain species, but include all species. Action thresholds are as follows: one thrips per plant during emergence to one true leaf, two thrips per plant during emergence to two true leaves, three thrips per plant during emergence to three leaves per plant (Texas A\&M Cotton Insect Management Guide 2017). Following emergence of five to seven leaves treatment is rarely justified (Texas A\&M Cotton Insect Management Guide 2017).

Biological Control: Minute pirate bugs, Orius insidiosus (Say), (Hemiptera: Anthocoridae) are the most effective predators of flower thrips in the genus Frankliniella (Funderburk et al. 2015a). Orius insidiosus prefer to feed on thrips larvae as Frankliniella tritici adults are more active and able to escape predation (Baez et al. 2004). In Florida, natural populations of Orius insidiosus invade eggplant and pepper fields during late spring and control thrips populations (Funderburk et al. 2015a). A predator-prey ratio of one Orius insidiosus to 180 thrips provides thrips suppression and one Orius insidiosus to 40 thrips provides control (Demirozer et al. 2012). Orius insidiosus is a common predator of thrips in numerous plant species such as cotton (Osekre et al. 2008).

Chemical control: Several insecticides are labelled for the use of Frankliniella tritici control in fruiting vegetables and cotton. However, chemical control is not recommended until after economic thresholds have been reached.

In an effort to conserve Orius insidiosus populations in fruiting vegetables, reduced-risk insecticides are recommended as opposed to broad-spectrum insecticides (Demirozer et al. 2012, Funderburk et al. 2015a, 2015b).

The primary means of chemical control for thrips in cotton relies on the use of insecticide-treated seed followed by the use of an in-furrow systemic insecticide once thresholds are reached (Texas A\&M Cotton Insect Management Guide).

\section{Selected References}

Arthurs S, Kok-Yokomi ML, Smith HA. 2015. Florida flower thrips (suggested common name) Frankliniella bispinosa Morgan (Insecta: Thysanoptera: Thripidae). Document EENY-639. UF/IFAS EDIS, Electronic Data Information Source. (29 October 2018)
Avila Y, Stavisky J, Hague S, Funderburk FE, Reitz R, Momol T. 2006. Evaluation of Frankliniella bispinosa (Thysanoptera: Thripidae) as a vector of the Tomato spotted wilt virusin pepper. Florida Entomologist 89: 204-207.

Baez I, Reitz SR, Funderburk JE. 2004. Predation by Orius insidiosus (Heteroptera: Anthocoridae) on life stages and species of Frankliniella flower thrips (Thysanoptera: Thripidae) in pepper flowers. Environmental Entomology 33: $662-670$.

Chellemi DO, Funderburk JE, Hall DW. 1994. Seasonal abundance of flower inhabiting Frankliniella species (Thysanoptera: Thripidae) on wild plant species. Environmental Entomology 23: 337-342.

Childers CC. 1997. Feeding and oviposition injuries to plants. Thrips as Crop Pests (ed. Lewis T), pp. 505-538. CAB International, Wallingford, UK.

Cluever J, Smith H. 2016. Pest information guide: Eastern flower thrips, Frankliniella tritici. Document IN113700. UF/IFAS EDIS, Electronic Data Information Source. (29 October 2018)

Cotton Insect Management Guide. 2017. Texas A\&M AgriLife Extension. (29 October 2018)

de Assis Filho FM, Stavisky J, Reitz R, Deom CM, Sherwood JL. 2005. Midgut infection by Tomato spotted wilt virus and vector incompetence of Frankliniella tritici. Journal of Applied Entomology 129: 548-550.

Demirozer O, Tyler-Julian K, Funderburk J, Leppla N, Reitz S. 2012. Frankliniella occidentalis (Pergande) integrated pest management programs for fruiting vegetables in Florida. Pest Management Science 68: 1537-1545.

Funderburk JE, Reitz S, Stansly P, Freeman J, Miller C, McAvoy G, Whidden A, Demirozer O, Nuessly G, Leppla N. 2015a. Managing thrips in pepper and eggplant. Document ENY-658 (IN401). UF/IFAS EDIS, Electronic Data Information Source. (29 October 2018)

Funderburk JE, Adkins S, Freeman J, Stansly P, Smith H, Demirozer O, Snodgrass C, Paret M, Leppla N. 2015b. Managing thrips and tospoviruses in tomato. Document ENY-859 (IN859). UF/IFAS EDIS, Electronic Data Information Source. (29 October 2018)

Hoddle MS, Mound LA, Paris DL. 2012. Thrips of California. CBIT Publishing, Queensland. (29 October 2018) 
Kirk WDJ. 2002. The pest and vector from the west: Frankliniella occidentalis. Thrips and Tospoviruses: Proceedings of the 7th International Symposium on Thysanoptera (Eds. Marullo R, Mound L), pp. 33-42. Australian National Insect Collection, Canberra, Australia.

Layton B, Reed JT. 2014. Biology and control of thrips on seedling cotton. Mississippi State University Extension Service. Publication 2302. (29 October 2018)

Paini DR, Funderburk JE, Jackson CT, Reitz SR. 2007. Reproduction of four thrips species (Thysanoptera: Thripidae) on uncultivated hosts. Journal of Entomological Science 42: 610-615.

Paini DR, Funderburk JE, Reitz SR. 2008. Competitive exclusion of worldwide invasive pest by a native. Quantifying competition between two phytophagous insects on two host plant species. Journal of Animal Ecology 77: 184-190.

Reed JT, Allen C, Bagwell R, Cook D, Burris E, Freeman B, Leonard R, Lentz G. 2006. A key to the thrips (Thysanoptera: Thripidae) on seedling cotton in the mid-southern United States. Mississippi Agricultural and Forestry Experiment Station Information Sheet. pp. 1-26.

Reitz SR. 2008. Comparative bionomics of Frankliniella occidentalis and Frankliniella tritici. Florida Entomologist 91: 474-476.

Reitz SR. 2009. Biology and ecology of the western flower thrips (Thysanoptera: Thripidae): The making of a pest. Florida Entomologist 92: 7-13.

Schuster DJ, Smith HA. 2015. Scouting for insects, use of thresholds, and conservation of beneficial insects on tomatoes. Document ENY685 (IN482). UF/IFAS EDIS, Electronic Data Information Source. (29 October 2018)

Toapanta M, Funderburk JE, Chellemi D. 2001. Development of Frankliniella species (Thysanoptera: Thripidae) in relation to microclimate temperatures in vetch. Journal of Entomological Science 36: 426-437. 